\title{
A scientific sampler
}

Mark Ridley

From Gaia to Selfish Genes: Selected Writings in the Life Sciences. Edited by Connie Barlow. MIT: 1991. Pp.273. \$17.50, £15.75.

CONNIE Barlow describes in her preface how her "childhood fascination for science" was "utterly quenched by schooling in science as facts", and she was only re-enchanted by the subject later, when she "chanced upon a lecture by James Lovelock". After that experience, she spent the next five years reading around in popular biology, particularly evolutionary biology, and had the idea of publishing together the more enjoyable passages she had come across.

From Gaia to Selfish Genes accordingly contains extracts from 33 authors. Each extract is quite short - the longest has 15 pages from The Selfish Gene by Richard Dawkins, (Oxford University Press, 1976) - and gives the reader a flavour of each author, rather than following through the ideas in their complete form. The main authors include: James Lovelock who, together with some other more-or-less moonstruck writers, treats the Earth as "the largest manifestation of life"; Lynn Margulis, who writes about symbiosis; Arthur Koestler and Ludwig von Bertalanffy, on the errors (as they see them) of the mechanical conception of life; R. Axelrod and William Hamilton, on tit-for-tat; E. O. Wilson, on sociobiology; Richard Lewontin and others on biological determinism; and Richard Dawkins. There are shorter pieces by, among others, Leslie Orgel and Francis Crick, and by F. Doolittle and C. Sapienza (on selfish DNA); by Ashley Montagu (on sociobiology), and by John Maynard Smith (on 'the way forward').

Maynard Smith summarizes

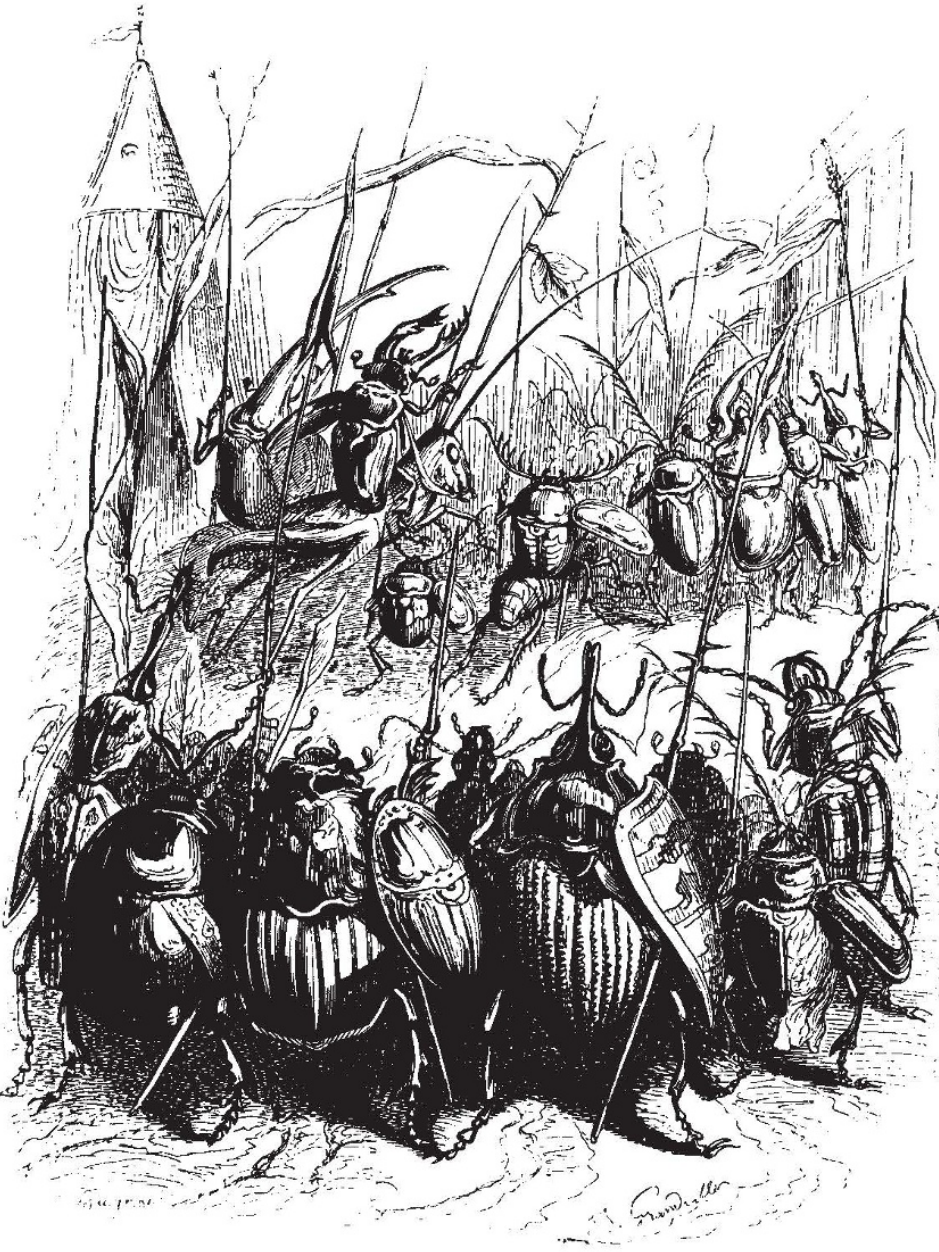

Richard Dawkins' coining of the word 'meme' in The Selfish Gene attracts the editorial eye of Connie Barlow in a chapter on the evolution of consciousness. The illustration is provided by "The heavy infantry of rebellious insects", Grandville's early nineteenth century engraving. the topics in the book with the question, "How should biologists think about the relationship between wholes and parts - that is, between ecosystems and the species that compose them, between organisms and cells, or between cells and genes?" From Gaia to Selfish Genes might seem to hint at one appropriate direction for thought on the subject; but that is not Barlow's titular intention. As Maynard Smith says, "I do not agree with the theories proposed by Lovelock, Margulis and Gould, but I am fascinated by the phe- nomena they discuss." Certainly, the extract from Lovelock here is unconvincing. He suggests that "the Earth is alive", and offers two arguments to support the proposition; one that the atmosphere is good (he says "optimal") for life, and another that living things provide feedback mechanisms which influence the atmospheric composition.

animal and human, are governed exclusively by genes": and he is juxtaposed with an essay by $\mathrm{E}$. O. Wilson which says that "human social evolution is obviously more cultural than genetic." And then, how could Lynn Margulis have persuaded herself that Dawkins' selfish genery is an "extreme" manifestation of the "reductionist view" that "biology is a subfield of chemistry and physics"? Where did Lewontin et al. find the "biological determinism" they criticize in the writings of the sociobiologists? Moreover, Lewontin et al.'s dialectical genetics, in which gene action depends on bodily context, looks to me exactly like the genetics of those politically less sophisticated biologists they believe to be "acting to preserve the interests of the dominant class, gender, and race."

Connie Barlow has edited the extracts carefully and the book is easy to read continuously from beginning to end. She intersperses comments to help the naive reader, and has packaged the prose with artwork illustrations, rather in the manner of the magazine The Sciences (Escher, Max Ernst, René Magritte, that sort of thing). The extracts are usually introduced by biographical material; the stuff about Lovelock and about Margulis almost amounts to a personality cult. It is mildly comic when these successful and much-honoured people try to pass themselves off as persecuted heretics, but the only truly ludicrous effect is provided by Carl Sagan, who appealed from a conference in Moscow to the clerics of the World "to join in an effort to save the planet". Whether they were persuaded is not recorded.

These personality cults fit in with Barlow's general aim, for she says she hopes "to encourage casual readers of nonfiction, devotees of popular physics, science majors, and students of the liberal arts to dig into the raft of appealing works in biology". My initial reaction is that any such readers who lay their hands on From Gaia to

These atmospheric properties, however, are most likely to be consequential, as both Doolittle and Maynard Smith point out, and not adaptive. In Lovelock's own illustrative model, selection on individuals to control their body temperature has consequences for global albedo.

One general impression from the book is of misunderstanding, much of it unnecessary. We see Lewis Thomas shaking his wise head over unnamed "imaginative scientists" who maintain "that all sorts of behaviour,
Selfish Genes will already be familiar with the popular authors it includes; but I may be wrong. The US educational system is, I fear, all too successful in putting students off science in exactly the way Barlow describes, and if her anthology attracts any of them back it will have served a noble purpose.

Mark Ridley is in the Department of Anthropology, Emory University, Atlanta, Georgia 30322, USA. 